\title{
Heterologous expression of an alginate lyase gene in mucoid and non-mucoid strains of Pseudomonas aeruginosa
}

\author{
Peter GaCesa $^{1 *}$ and Joanna B. Goldberg ${ }^{2}$ \\ ${ }^{1}$ Department of Biochemistry, University of Wales College of Cardiff, PO Box 903, Cardiff CF1 1ST, UK \\ ${ }^{2}$ Channing Laboratory, Brigham and Women's Hospital, Harvard Medical School, Boston, MA 02115, USA
}

(Received 20 January 1992; revised 9 April 1992; accepted 30 April 1992)

\begin{abstract}
A $1.95 \mathrm{~kb}$ DNA fragment containing the aly gene from Klebsiella pneumoniae, which encodes an alginate lyase, has been ligated into the broad-host-range vector pLAFR3. Transfer of the resultant recombinant plasmid, pALY8, into mucoid and non-mucoid strains of Pseudomonas aeruginosa resulted in expression of the alginate lyase. The heterologously expressed alginate lyase, which had the same isoelectric point and substrate specificity as the native enzyme, altered the morphology of mucoid strains. Analysis of the extracellular material from mucoid strains revealed that lyase expression reduced the $M_{\mathrm{r}}$ and overall yield of alginate produced. The mature form of the recombinant enzyme was the same as that produced extracellularly by Klebsiella pneumoniae; however, most of the alginate lyase was retained intracellularly by $\boldsymbol{P}$. aeruginosa.
\end{abstract}

\section{Introduction}

Pseudomonas aeruginosa is an opportunistic pathogen that causes a variety of infections in compromised patients. In chronic infections a mucoid, exopolysaccharide-producing form of the organism tends to predominate and is invariably associated with a poorer prognosis for the patient. The exopolysaccharide, alginate, is an important virulence factor synthesized by mucoid strains of Pseudomonas aeruginosa (Gacesa \& Russell, 1990). Approximately $80 \%$ of the isolates of $P$. aeruginosa from cystic fibrosis patients are mucoid, i.e. alginate-producing (Doggett et al., 1966), and in other chronic clinical conditions a significant but lower incidence of mucoid isolates has also been observed (McAvoy et al., 1989). Many mechanisms have been proposed for the role of alginate in pathogenesis and it appears that there is a complex interaction between the polysaccharide, the immune system and cell-surface components within the lungs of cystic fibrosis patients (Gacesa \& Russell, 1990). Alginate is also synthesized by phytopathogenic pseudomonads, where it has been implicated as a virulence factor (Fett et al., 1986; Osman et al., 1986). Other pseudomonads (Govan et al., 1981) and Azotobacter vinelandii (Anderson et al., 1987) also synthesize alginate under appropriate environmental conditions.

Alginates are (1-4)-linked glycuronans comprised of residues of $\beta$-D-mannuronate and the C5-epimer $\alpha-\mathrm{L}$ guluronate. These monomers are arranged in block

* Author for correspondence. Tel. 0222 874128; fax 0222 874116; email gacesa@uk.ac.cardiff.

0001-7348 (C) 1992 SGM structures which may be homopolymeric [poly $\beta$-Dmannuronate (poly $\mathbf{M}$ ) or poly $\alpha$-L-guluronate (poly $\mathrm{G}$ )] or heteropolymeric, occurring as random sequences (poly MG). The alginate produced by $P$. aeruginosa is devoid of poly $\mathrm{G}$ blocks and many of the $\mathrm{D}$-mannuronate residues are $O$-acetylated at the 2 and/or 3 positions, unlike the alginate obtained from non-bacterial sources (Gacesa, 1988). The physical and chemical properties of alginates are dependent on the proportions of the various block structures within the polysaccharide chains and on the degree of $O$-acetylation. Alginates with a large proportion of poly $\mathrm{G}$ blocks form strong but brittle gels in the presence of divalent cations, especially $\mathrm{Ca}^{2+}$, whereas those rich in the other block structures form weaker but more flexible gels. The types of alginate produced by clinical isolates of $P$. aeruginosa, i.e. no poly G blocks, $O$-acetylated and high $M_{\mathrm{r}}$, result in the formation of relatively bulky gels with a high degree of water retention.

Alginates are degraded by a group of enzymes that catalyse the $\beta$-elimination of the $4-O$-linked glycosidic bond with formation of unsaturated uronic-acid-containing oligosaccharides (Gacesa, 1987). These alginate lyases have been reported from a wide variety of bacterial and other sources and typically show preference for one or more of the block structures in alginate (Gacesa, 1992). A 'mannuronate-specific' alginate lyase has been detected in approximately $50 \%$ of isolates of mucoid $P$. aeruginosa (Dunne \& Buckmire, 1985; Linker \& Evans, 1984). The gene for a 'guluronate-specific' alginate lyase from Klebsiella pneumoniae has been cloned and the recombinant enzyme expressed in Escherichia 
coli (Caswell et al., 1989). Although this enzyme preferentially degrades regions of alginate containing Lguluronate, it also degrades random block structures and alginate derived from isolates of mucoid $P$. aeruginosa.

The clinical management of mucoid $P$. aeruginosa infections in the lungs of cystic fibrosis patients has proved to be difficult. A complex regime of antibiotic therapy and physiotherapy is required to control mucoid $P$. aeruginosa and typically these infections become asymptomatic for varying periods before recurrence of the infection (Dinwiddie, 1990). One suggested approach to therapy has been the use of alginate lyases to degrade the alginate and aid dispersal of the bacterial infection by either physiotherapy or antibiotic treatment (Russell \& Gacesa, 1988).

In this paper we report the cloning of an alginate lyase gene into mucoid and non-mucoid strains of $P$. aeruginos $a$ and the effects of heterologous expression on the properties of the bacterial alginate. This provides a useful model system for studying the effects of alginate lyase on the exopolysaccharide produced by mucoid strains of $P$. aeruginosa.

\section{Methods}

Bacterial strains, plasmids and media. The bacterial strains and plasmids used in this work are listed in Table 1. Strains of $E$. coli and $P$. aeruginosa were grown with aeration in $\mathrm{L}$ broth (Tryptone, $10 \mathrm{~g}$; yeast extract, $5 \mathrm{~g} ; \mathrm{NaCl}, 5 \mathrm{~g} \mathrm{l}^{-1}$ ) at $37^{\circ} \mathrm{C}$. Antibiotics were used in selective media at the following concentrations: ampicillin $\left(50 \mu \mathrm{g} \mathrm{ml}^{-1}\right.$ for $E$. coli), tetracycline $\left(10 \mu \mathrm{g} \mathrm{ml}^{-1}\right.$ for E. coli; $100 \mu \mathrm{g} \mathrm{ml}^{-1}$ for P. aeruginosa). Media were solidified by the addition of $15 \mathrm{~g}_{\text {agar } ~^{-1}}$.

Expression of alginate lyase activity was detected by growth on L-broth, containing appropriate antibiotics, solidified with $1 \%(w / v)$ agarose and containing $0.1 \%$ sodium alginate (high-viscosity alginate from Macrocystis pyrifera; Sigma). Clearing zones were detected following addition of $10 \%(w / v)$ cetyl pyridinium chloride (Gacesa \& Wusteman, 1990).

A minimal medium was used to grow bacteria for the subcellular localization of alginate lyase. P. aeruginosa was grown overnight at $37^{\circ} \mathrm{C}$ on M9-salts with D-gluconate as the carbon source and supplemented with amino acids and antibiotics as appropriate.

Construction and manipulation of recombinant plasmids. DNA manipulations were performed as described by Sambrook et al. (1989). The recombinant plasmid pRC5 (Caswell et al., 1989) was used as the source of a $1.95 \mathrm{~kb}$ HindIII fragment which contained the alginate lyase gene from Klebsiella pneumoniae. The $1.95 \mathrm{~kb}$ fragment was inserted into the HindIII site of the broad-host-range vector pLAFR3 and transformed into E. coli JM107. Clones expressing alginate lyase, as detected using alginate/agarose plates, were used as donors in triparental mating experiments. Recombinant DNA was mobilized into mucoid and non-mucoid strains of $P$. aeruginosa by triparental mating using the conjugative helper plasmid pRK2013 (Goldberg \& Ohman, 1984). Recipient strains of $P$. aeruginosa were selected by growth on Vogel and Bonner minimal medium containing tetracycline (Goldberg \& Ohman, 1984). The donor strain of E. coli is unable to grow in the absence of thiamin and the helper strain is sensitive to tetracycline. Transconjugants capable of expressing alginate lyase were detected by zones of clearing on alginate agarose plates.

Purification and analysis of polysaccharides. P. aeruginosa was grown on L-agar plates at $37^{\circ} \mathrm{C}$ for $72 \mathrm{~h}$. The growth from three plates was gently removed with a glass rod, centrifuged and the supernatant, containing water-soluble polysaccharide, was dialysed and freeze-dried (Sherbrock-Cox et al., 1984). This material was analysed for total carbohydrate, uronic acid and protein prior to further purification. The crude freeze-dried extract was redissolved in a minimum of distilled water and cetyl pyridinium chloride (CPC) added to a final concentration of $2 \%(\mathrm{w} / \mathrm{v})$ to precipitate the alginate. The alginate/ CPC complex was collected by centrifugation $(5000 \mathrm{~g}$ for $10 \mathrm{~min}$ at $4{ }^{\circ} \mathrm{C}$ ) and the alginate redissolved by the slow addition of solid $\mathrm{NaCl}$ (final concentration $1 \mathrm{M}$ ) (Narbad et al., 1988). Further purification was achieved by the addition of an equal volume of propan-2-ol to precipitate the alginate. The precipitate was redissolved in water, the propan-2-ol precipitation procedure repeated once and samples freezedried.

Protein was measured by the method of Bradford (1976) with bovine serum albumin as standard. Total carbohydrate was assayed with phenol/sulphuric acid reagent (Dubois et al., 1956) and uronic acids with 3-phenylphenol/borate reagent (Blumenkrantz \& Asboe-Hansen, 1973) with D-mannurono 6,3-lactone as standard. The $O$-acetyl content of the alginate sample was assayed by the method of Buscher et al. (1974) with $\beta$-D-glucose penta-acetate as standard.

Samples of purified alginates were analysed by ${ }^{1} \mathrm{H}-\mathrm{NMR}$ as described previously (McAvoy et al., 1989). The $M_{\mathrm{r}}$ distributions of alginate preparations were determined by gel permeation chromato-

Table 1. Bacterial strains and plasmids

\begin{tabular}{|c|c|c|}
\hline Strain or plasmid & Genotype or phenotype & Reference \\
\hline $\begin{array}{l}\text { Bacteria } \\
\text { E. coli } \\
\text { JM107 }\end{array}$ & $\Delta\left(\right.$ lac-pro) thi gyr 996 endAl hsdRI7 relAl supE44 merA $\left(\mathrm{F}^{\prime}\right.$ traD36 proAB lacl $\left.{ }^{\circ} \mathrm{Z} \Delta \mathrm{M} 15\right)$ & Yanisch-Perron et al. (1985) \\
\hline $\begin{array}{l}\text { P. aeruginosa } \\
\text { AK } 957 \\
\text { FRD } 1 \\
\text { FRD } 130\end{array}$ & $\begin{array}{l}\text { PAOl equivalent, prototrophic, } \mathrm{Alg}^{-} \\
\text {Prototrophic, } \mathrm{Alg}^{+} \text {cystic fibrosis isolate } \\
\text { met-1, arg-1, trp- } 2, \mathrm{Nal}^{r}, \mathrm{Alg}^{+} \text {stable }\end{array}$ & $\begin{array}{l}\text { A. Kropinski, Kingston, Ontario } \\
\text { Ohman \& Chakrabarty (1981) } \\
\text { Goldberg \& Ohman (1984) }\end{array}$ \\
\hline $\begin{array}{l}\text { Vectors } \\
\text { pALY8 } \\
\text { pLAFR3 } \\
\text { pRC5 } \\
\text { pRK2013 }\end{array}$ & $\begin{array}{l}\text { pLAFR3 with } 1.95 \mathrm{~kb} K . \text { pneumoniae DNA containing aly } \\
\text { IncP } \mathrm{Tc}^{r} \lambda \cos ^{+} \\
\text {pHG327 with } 1.95 \mathrm{~kb} K \text {. pneumoniae DNA containing aly } \\
\text { ColE1-Tra(RK2) })^{+} \mathrm{Km}^{\mathrm{r}}\end{array}$ & $\begin{array}{l}\text { This paper } \\
\text { Staskawicz et al. (1987) } \\
\text { Caswell et al. }(1989) \\
\text { Figurski \& Helinski (1979) }\end{array}$ \\
\hline
\end{tabular}


graphy on Sepharose CL-4B. Alginate samples (approximately $1 \mathrm{mg}$ ) were eluted from the column at a flow rate of $0.83 \mathrm{ml} \mathrm{min} \mathrm{m}^{-1}$ and fractions $(2 \mathrm{ml})$ were analysed for uronic acid using the 3-phenylphenol/ borate reagent.

Properties of the recombinant gene products. Crude preparations of intracellular and extracellular enzyme were prepared and assayed as described previously (Caswell et al., 1986). Enzyme degradation of sodium alginate was monitored by measuring either the release of reducing sugar equivalents or the increase in absorbance at $232 \mathrm{~nm}$ (Boyd \& Turvey, 1977). One unit of enzyme activity is defined as the release of $1 \mu \mathrm{mol}$ reducing sugar $\mathrm{min}^{-1}$ under the conditions of assay. The substrate specificity of the recombinant enzyme was determined using samples of characterized algal and bacterial alginate, and specific block structures which were prepared as described previously (Gacesa \& Wusteman, 1990).

The isoelectric point of alginate lyase was determined by isoelectric focusing and detection of enzyme activity by a substrate-overlay technique (Caswell et al., 1986).

Sub-cellular localization of the alginate lyase. Strains of $P$. aeruginosa were grown overnight at $37^{\circ} \mathrm{C}$ on M9-salts containing D-gluconate as carbon source and supplemented with amino acids and antibiotics as appropriate. Extracellular, periplasmic and cytoplasmic fractions were obtained as described previously (Cheng et al., 1970).

\section{Results}

Isolation of clones containing the aly gene

The cloned alginate lyase gene, aly, on a $1.95 \mathrm{~kb}$ HindIII fragment was ligated into the single HindIII site in the broad-host-range plasmid pLAFR3 as described in Methods. Plasmids were transformed into E. coli JM107 selected for the plasmid-encoded tetracycline resistance and screened for alginate lyase activity, as detected by clearing zones on alginate/agarose plates. Plasmids were isolated from $\mathrm{Aly}^{+}$E. coli transformants and restriction endonuclease digestion of plasmid DNA with HindIII was used to confirm the acquisition of the $1.95 \mathrm{~kb}$ HindIII fragment into pLAFR3. The recombinant plasmid was then transferred to $P$. aeruginosa by triparental mating and all transconjugants produced alginate lyase as detected by clearing zones on alginate/ agarose plates. The absence of detectable endogenous alginate lyase was confirmed as control strains containing pLAFR3 alone did not produce clearing zones under these experimental conditions. Analysis of plasmid DNA by restriction digestion and electrophoresis on agarose gels confirmed that all $\mathrm{Aly}^{+}$transconjugants tested contained a $1.95 \mathrm{~kb}$ insert in pLAFR3. The recombinant plasmid containing the $1.95 \mathrm{~kb}$ insert was designated pALY8.

The phenotypes of the transconjugants grown on Lagar were compared to control strains containing vector alone. Non-mucoid transconjugants containing pALY8 showed no alteration in morphology. However, mucoid transconjugants containing pALY8 had a less mucoid

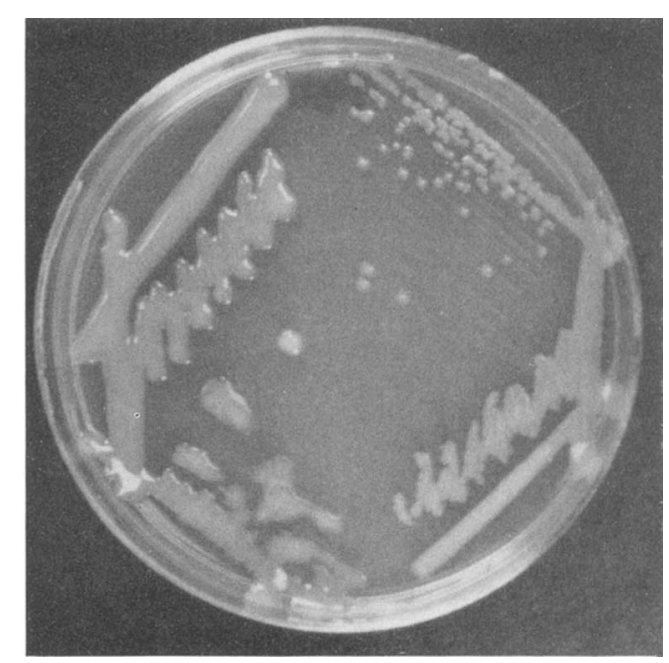

Fig. 1. Colonial morphology on L-agar of the 'mucoid' strain FRD 1 containing vector (pLAFR3; left) or the recombinant plasmid (pALY8) which contains the $1.95 \mathrm{~kb}$ fragment encoding alginate lyase (right).

appearance at low cell density and were essentially nonmucoid at high cell density (Fig. 1).

\section{Localization of the alginate lyase activity}

The bulk of the alginate lyase was retained in the cytoplasm of the non-mucoid strain, with small but detectable activity in the periplasmic fraction. Subcellular fractionation of mucoid strain FRD 1(pALY 8) showed that almost one-third of the enzyme was present in the medium (Table 2).

\section{Effects of alginate lyase on the properties of alginate}

The crude water-soluble extracellular material produced by transconjugants of $P$. aeruginosa contained carbohydrate, uronic acid and small amounts of protein $(<3 \%$, $\mathrm{w} / \mathrm{w})$. Analysis of the purified material from transconjugants containing pALY 8 revealed that only $14-19 \%$ of the carbohydrate was uronic acid. In contrast, transconjugants containing vector alone produced polysaccharide which was $87-92 \%$ uronic acid (Table 3 ). ${ }^{1} \mathrm{H}-\mathrm{NMR}$ analysis of the material from the control bacteria gave a spectrum typical of alginate, whereas spectra of polysaccharide from transconjugants containing pALY8 lacked the peaks at 4.65 and 5.05 p.p.m. which are characteristic of alginates. The alginates derived from FRD 1 and FRD 130 were identical, with a guluronate content of $34 \%$ and a nearest-neighbour fractional composition of $\mathrm{F}_{\mathrm{GG}}=0$, $\mathrm{F}_{\mathrm{MM}}=0.32$ and $\mathrm{F}_{\mathrm{MG}}+\mathrm{F}_{\mathrm{GM}}=0.68$.

The $M_{\mathrm{r}}$ profiles of alginate from $P$. aeruginosa on gel permeation chromatography showed significant differ- 
Table 2. Cellular distribution of alginate lyase activity

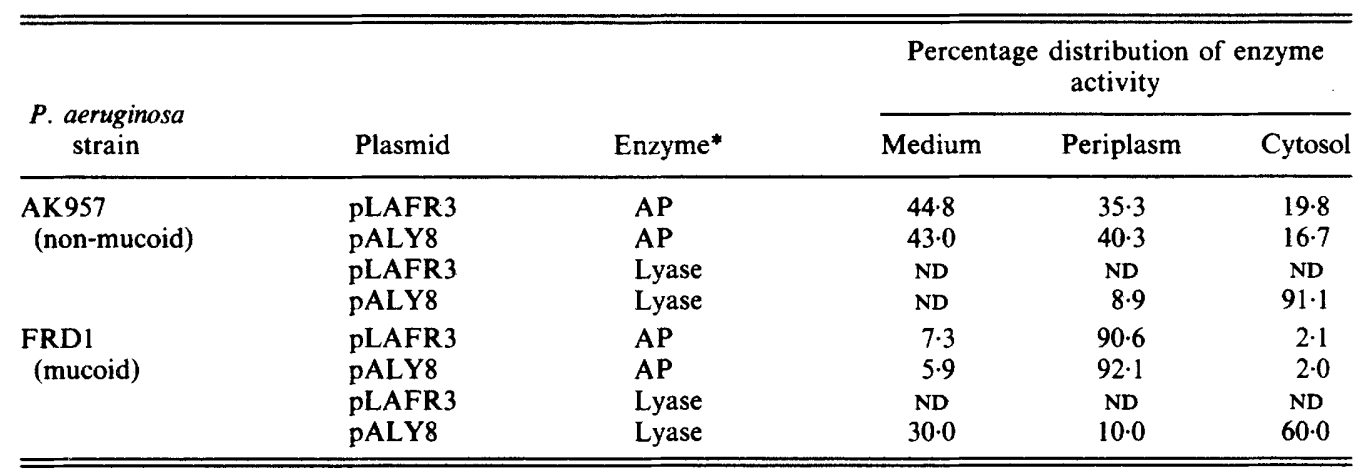

ND, Not detected.

*AP, alkaline phosphatase (periplasmic marker enzyme).

Table 3. Analysis of extracellular material from cultures of $P$. aeruginosa

\begin{tabular}{|c|c|c|c|c|c|}
\hline \multirow[b]{2}{*}{ Strain } & \multirow[b]{2}{*}{ Plasmid } & \multirow{2}{*}{$\frac{\text { Crude material }}{\begin{array}{c}\text { Percentage } \\
\text { uronic acid }\end{array}}$} & \multicolumn{3}{|c|}{ Cetyl trimethylammonium bromide-purified material } \\
\hline & & & $\begin{array}{l}\text { Percentage } \\
\text { uronic acid }\end{array}$ & $\begin{array}{l}\text { O-Acetyl/uronate } \\
\text { ratio }\end{array}$ & $\begin{array}{c}O \text {-Acetyl } / \text { mannuronate } \\
\text { ratio }\end{array}$ \\
\hline FRD 1 & pLAFR3 & $55 \cdot 7$ & $86 \cdot 8$ & 0.75 & $1 \cdot 12$ \\
\hline FRD 1 & pALY8 & $14 \cdot 1$ & $19 \cdot 0$ & 0.74 & $\mathrm{ND}^{*}$ \\
\hline FRD 130 & pLAFR3 & 59.9 & 91.9 & 0.76 & $1 \cdot 15$ \\
\hline FRD 130 & pALY 8 & $12 \cdot 5$ & $14 \cdot 5$ & $0 \cdot 73$ & ND* \\
\hline Manucol DH $\dagger$ & & $87 \cdot 5$ & $91 \cdot 1$ & NA $\ddagger$ & NA $\ddagger$ \\
\hline
\end{tabular}

* Insufficient material available to determine the mannuronate to guluronate ratio.

$\dagger$ A sample of algal alginate.

$\ddagger$ Not applicable as algal alginate is devoid of $O$-acetyl groups.

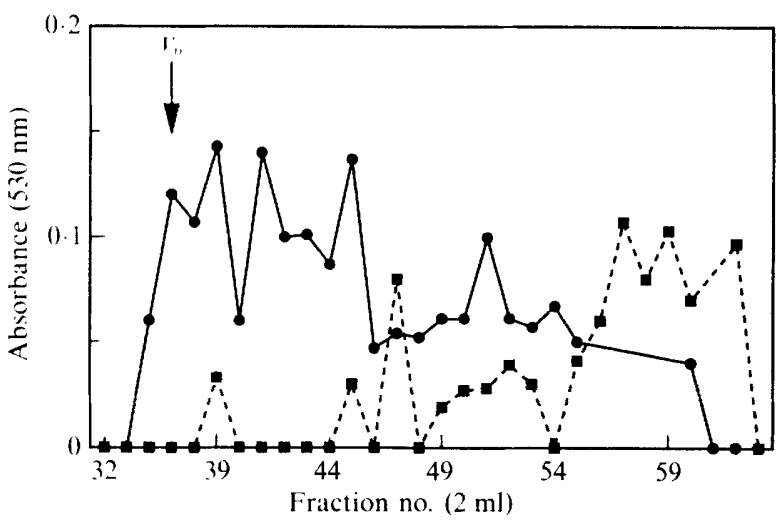

Fig. 2. $M_{\mathrm{r}}$ profile of alginate derived from mucoid strains of $P$. aeruginosa. Samples of alginate from $P$. aeruginosa containing the recombinant plasmid, pALY8 (dashed line) or vector, pLAFR3 (solid line) were chromatographed on a column of Sepharose 4B-CL. Experimental details are described in Methods. $V_{0}$ indicates the void volume of the column.

ences between strains. Alginate of lower $M_{\mathrm{r}}$ was produced by those bacteria which contained pALY8 and expressed the alginate lyase (Fig. 2).
Table 4. Substrate specificity of native and recombinant alginate lyase

\begin{tabular}{llc}
\hline \hline \multirow{2}{*}{ Substrate } & \multicolumn{2}{c}{ Relative activity } \\
\cline { 2 - 3 } & $\begin{array}{c}\text { Native } \\
\text { enzyme }\end{array}$ & $\begin{array}{c}\text { Recombinant } \\
\text { enzyme }\end{array}$ \\
\hline Oligomeric & & \\
Random block & $1.00^{*}$ & $1.00 \dagger$ \\
Poly M block & 0.41 & 0.36 \\
Poly G block & 0.86 & 0.88 \\
Polymeric & & \\
Manucol DH (algal alginate) & 0.77 & 0.85 \\
CF492a (Pseudomonas alginate) & 0.25 & 0.27 \\
\hline \hline
\end{tabular}

* Measured activity was $28 \mathrm{nmol}$ product produced $\min ^{-1}$.

$\dagger$ Measured activity was $85 \mathrm{nmol}$ product produced min $^{-1}$.

\section{Properties of the alginate lyase}

The recombinant enzyme expressed by $P$. aeruginosa had the same substrate specificity as the alginate lyase expressed by the $K$. pneumoniae strain from which the original aly gene had been obtained. The recombinant 
enzyme degraded polymeric algal alginate (Manucol $\mathrm{DH}$ ), bacterial alginate and various block structures, and had the same ratio of activities towards the substrates as the native enzyme. Poly G and poly MG blocks were degraded preferentially, with less degradation of poly $\mathbf{M}$ (Table 4).

\section{Isoelectric focusing}

Both the native and recombinant alginate lyases produced identical patterns on isoelectric focusing gels, with activity detected at a pI value of 8.9.

\section{Discussion}

The expression of the Klebsiella alginate lyase in mucoid $P$. aeruginosa affects the properties of the alginate produced by this organism. Evidence for enzyme activity is based on the observable clearing zones on alginate/ agarose plates, the altered morphology and the fractionation and quantitative estimate of extracellular material. It is unlikely that the observed effects are due to reversion of the mucoid strains rather than the effect of the lyase. No evidence of abnormal rates of reversion was noted in mucoid $P$. aeruginosa transconjugants containing the vector alone. Also, the same alteration of morphology was noted in both the wild-type organism, FRD 1, and the stable mucoid derivative FRD 130.

The expressed alginate lyase in the recombinant isolates of $P$. aeruginosa had the same isoelectric point and substrate specificity as the native enzyme from $K$. pneumoniae. Therefore, the observed enzyme activity is due to expression of the $K$. pneumoniae aly gene rather than to induced endogenous activity. Although alginate lyase activity has been observed in up to $50 \%$ of clinical mucoid isolates of $P$. aeruginosa (Dunne \& Buckmire, 1985; Linker \& Evans, 1984), no endogenous alginate lyase was observed in our strains under the culture conditions used. It is conceivable that all strains of $P$. aeruginosa possess a gene(s) for an alginate lyase but this is likely to be tightly regulated, as is the case for genes involved in alginate biosynthesis (Mohr et al., 1990).

The alginate lyase was located predominantly in the cytoplasm or periplasmic space in non-mucoid $P$. aeruginosa. However, a significant proportion of the enzyme activity was located extracellularly in the mucoid strain, although this may have been partly due to cell lysis. The enzyme in $K$. pneumoniae is located extracellularly (Caswell et al., 1989) although there have been reports that substantial quantities of lyase remain in the bacterial cell (Lange et al., 1989). Expression of the aly gene in $E$. coli results in production of a pro-enzyme (Caswell \& Gacesa, 1990b) which is processed to the mature form of the lyase and exported into the periplasm or medium (Caswell \& Gacesa, 1990a). The fact that expression of the aly gene in $P$. aeruginosa results in a protein with a pI of 8.9 , i.e. identical to the mature protein in $K$. pneumoniae, implies that $P$. a.ruginosa is able to process the pro-protein although export is less effective and may be deficient. However, it is conceivable that growth rate or the age of the culture may influence the amount of enzyme that is exported by $P$. aeruginosa. This is undoubtedly the case with K. pneumoniae (Caswell \& Gacesa, 1990b). Some other periplasmic enzymes of $K$. pneumoniae, e.g. pullulanase, are exported from the bacterial cell as lipoprotein complexes (D'Enfert et al., 1987); however, there is no evidence that this is the case with alginate lyase.

The secretion of a greater proportion of the alginate lyase by the mucoid compared to the non-mucoid strain may be the result of any one of a number of effects. For example, the measurable endogenous exolipase activity of $P$. aeruginosa is greater in alginate-producing strains (Wingender \& Winkler, 1984) and it has been proposed that alginate promotes the release of exolipase from the lipopolysaccharides of the outer membrane (Wingender, 1990). In contrast, it has been reported that mucoid strains of $P$. aeruginosa secrete less elastase than their non-mucoid counterparts (Ohman \& Chakrabarty, 1982; Goldberg \& Ohman, 1987). However, this probably reflects transcriptional control in the latter example rather than the release of latent enzyme from the surface of the outer membrane (Goldberg \& Ohman, 1987; Mohr et al., 1990).

It will be interesting to study the virulence of the recombinant strains. Alginate has been reported to inhibit phagocytosis of $P$. aeruginosa by acting as a freeradical scavenger (Smith \& Simpson, 1990). This is supported by other studies which indicate that alginate lyase treatment of mucoid $P$. aeruginosa enhances phagocytosis of the bacteria by human monocytederived macrophages (Eftekhar \& Speert, 1988). The availability of recombinant strains containing the aly gene is a useful model system. Such a model system will allow the problems outlined above to be investigated more thoroughly than has been possible hitherto, as the alginate lyase may be expressed in the recombinant organism in a controlled manner.

P.G. is grateful to the Cystic Fibrosis Research Trust (UK) for financial support for this and related work. We are also grateful to P. J. Tatnell for analysing the polysaccharide samples.

\section{References}

Anderson, A. J., Hacking, A. J. \& Dawes, E. A. (1987). Alternative pathways for the biosynthesis of alginate from fructose and glucose in Pseudomonas aeruginosa and Azotobacter vinelandii. Journal of General Microbiology 133, 1045-1052. 
Blumenkrantz, N. \& Asboe-Hansen, G. (1973). New method for quantitative determination of uronic acids. Analytical Biochemistry 54, 484-489.

BOYD, J. \& TURVEY, J. R. (1977). Isolation of a poly- $\alpha$-L-guluronate lyase from Klebsiella aerogenes. Carbohydrate Research 57, 163-171.

BRADFORD, M. (1976). A rapid and sensitive method for the quantitation of microgram quantities of protein utilizing the principle of protein-dye binding. Analytical Biochemistry 92, 248254.

Buscher, H. P., Casals-Stenzel, J. \& Schauer, R. (1974). New sialic acids. Identification of $\mathrm{N}$-glycoloyl-O $\mathrm{O}$-acetylneuraminic acids and $\mathrm{N}$ acetyl- $O$-glycoloylneuraminic acids by improved methods for detection of $\mathrm{N}$-acyl and $\mathrm{O}$-acyl groups and by gas-liquid chromatography. European Journal of Biochemistry 50, 71-82.

CAswell, R. C. \& GaCESA, P. (1990a). Heterologous expression and cellular distribution in Escherichia coli of the gene from Klebsiella pneumoniae which encodes alginate lyase. Brochemical Society Transactions 18, 929-930.

CASWELL, R. C. \& GACESA, P. (1990 b). In vitro transcription translation of the alginate lyase gene from Klebsiella pneumoniae and detection of a precursor form of the enzyme. Biochemical Society Transactions 18, 927-928.

Caswell, R. C., Gacesa, P. \& Weightman, A. J. (1986). Detection of alginate lyases by isoelectric focusing and activity staining. International Journal of Biological Macromolecules 8, 337-341.

Caswell, R. C., Gacesa, P., Lutrell, K. E. \& Weightman A. J. (1989). Molecular cloning and heterologous expression of a Klebsiella pneumoniae gene encoding alginate lyase. Gene 75, 127-134.

Cheng, K. J., Ingram, J. M. \& Costerton, J. W. (1970). Alkaline phosphatase localization and spheroplast formation of Pseudomonas aeruginosa. Canadian Journal of Microbiology 16, 1319-1324.

D'Enfert, C., Chapon, C. \& Pugsley, A. P. (1987). Export and secretion of the lipoprotein pullulanase by Klebsiella pneumoniae. Molecular Microbiology 1, 107-116.

DinwidDIE, R. (1990). Clinical aspects of mucoid Pseudomonas aeruginosa infections. In Pseudomonas Infection and Alginates, pp. 1328. Edited by P. Gacesa \& N. J. Russell. London: Chapman \& Hall.

Doggett, R. G., Harrison, G. M., Stillwell, R. N. \& Wallis, E. S. (1966). An atypical Pseudomonas aeruginosa associated with cystic fibrosis of the pancreas. Journal of Pediatrics 68, 215-221.

Dubois, M., Gilles, K. A., Hamilton, J. K., Rebers, P. A. \& SMith, F. (1956). Colorimetric method for determination of sugars and related substances. Analytical Chemistry 28, 350-356.

DUNNe, W. M., JR \& BUCKMIRE, F. L. A. (1985). Partial purification and characterization of a polymannuronic acid depolymerase produced by a mucoid strain of Pseudomonas aeruginosa isolated from a patient with cystic fibrosis. Applied and Environmental Microbiology 50, 562-567.

EfTeKhar, F. \& SPEerT, D. P. (1988). Alginase treatment of mucoid Pseudomonas aeruginosa enhances phagocytosis by human monocytederived macrophages. Infection and Immunity 56, 2788-2793.

FetT, W. F., Osman, S. F., Fishman, M. C. \& Siebles, T. S., III (1986). Alginate production by plant-pathogenic Pseudomonads. Applied and Environmental Microbiology 52, 466-473.

Figurski, D. \& HeLINSKI, D. R. (1979). Replication of an origincontaining derivative of plasmid RK2 dependent on a plasmid function provided in trans. Proceedings of the National Acadamy of Sciences of the United States of America 76, 1648-1652.

GaCESA, P. (1987). Alginate modifying enzymes. A proposed unified mechanism of action for the lyases and epimerases. FEBS Letters 212, 199-202

GaCeSA, P. (1988). Alginates. Carbohydrate Polymers 8, 161-182.

GACESA, P. (1992). Enzymic degradation of alginates. International Journal of Biochemistry 24, 545-552.

Gacesa, P. \& Russell, N. J. (editors) (1990). Pseudomonas Infection and Alginates. London: Chapman \& Hall.

GaCesa, P. \& Wusteman, F. S. (1990). Plate assay for simultaneous detection of alginate lyases and determination of substrate specificity. Applied and Environmental Microbiology 56, 2265-2267.
GoldberG, J. B. \& Ohman, D. E. (1984). Cloning and expression in Pseudomonas aeruginosa of a gene involved in the production of alginate. Journal of Bacteriology 158, 1115-1121.

GoldberG, J. B. \& OHMAN, D. E. (1987). Cloning and transcriptional regulation of the elastase las $A$ gene in mucoid and nonmucoid Pseudomonas aeruginosa. Journal of Bacteriology 169, 1349 1351.

Govan, J. R. W., FYFE, J. A. M. \& JARMAN, T. R. (1981). Isolation of alginate-producing mutants of Pseudomonas fluorescens, Pseudomonas putida and Pseudomonas mendocina. Journal of General Microbiology 125, 217-220.

LANGE, B., WingeNDER, J. \& WinkLER, U. K. (1989). Isolation and characterization of an alginate lyase from Klebsiella aerogenes. Archives of Microbiology 152, 302-308.

LINKER, A. \& EvANS, L. R. (1984). Isolation and characterization of an alginase from mucoid strains of Pseudomonas aeruginosa. Journal of Bacteriology 159, 958-964.

Mcavoy, M. J., Newton, V., Paull, A., Morgan, J., Gacesa, P. \& RuSSELL, N. J. (1989). Isolation of mucoid strains of Pseudomonas aeruginosa from non-cystic-fibrosis patients and characterisation of the structure of their secreted alginate. Journal of Medical Microbiology 28, 183-189.

Mohr, C. D., Rust, L., Albus, A. M., Iglewski, B. H. \& Deretic, V. (1990). Expression patterns of genes encoding elastase and controlling mucoidy: co-ordinate regulation of two virulence factors in Pseudomonas aeruginosa isolates from cystic fibrosis. Molecular Microbiology 4, 2103-2110.

Narbad, A., Russell, N. J. \& Gacesa, P. (1988). Radiolabelling patterns in alginate of Pseudomonas aeruginosa synthesised from specifically-labelled ${ }^{14} \mathrm{C}$-monosaccharide precursors. Microbios $\mathbf{5 4}$, 171-179.

Ohman, D. E. \& Chakrabarty, A. M. (1981). Genetic mapping of chromosomal determinants for the production of the exopolysaccharide alginate in a Pseudomonas aeruginosa cystic fibrosis isolate. Infection and Immunity 33, 142-148.

Ohman, D. E. \& Chakrabarty, A. M. (1982). Utilization of human respiratory secretion by mucoid Pseudomonas aeruginosa of cystic fibrosis origin. Infection and Immunity 37, 662-669.

OSMAN, S. F., FETT, W. F. \& Fishman, M. L. (1986). Exopolysaccharides of the phytopathogen Pseudomonas syringae pv. glycinea. Journal of Bacteriology 166, 66-71.

Russell, N. J. \& GaCeSA, P. (1988). Chemistry and biology of the alginate of mucoid strains of Pseudomonas aeruginosa in cystic fibrosis. Molecular Aspects of Medicine 10, 1-91.

SAMBroOK, J., Fritsch, E. F. \& Maniatis, T. (1989). Molecular Cloning - a Laboratory Manual, 2nd edn. Cold Spring Harbor, NY: Cold Spring Harbor Laboratory.

Sherbrock-Cox, V., Russell, N. J. \& Gacesa, P. (1984). The purification and chemical characterisation of the alginate present in the extracellular material produced by mucoid strains of Pseudomonas aeruginosa. Carbohydrate Research 135, 147-154.

Smith, S. E. \& Simpson, J. A. (1990). The contribution of Pseudomonas aeruginosa alginate to evasion of host defence. In Pseudomonas Infection and Alginates, pp. 135-159. Edited by P. Gacesa \& N. J. Russell. London: Chapman \& Hall.

Staskawicz, B., Dahlbeck, D., Keen, N. \& Napoli, C. (1987). Molecular characterization of cloned avirulence genes from race 0 and race 1 of Pseudomonas syringae pv. glycinea. Journal of Bacteriology 169, 5789-5794.

WINGENDER, J. (1990). Interactions of alginate with exoenzymes. In Pseudomonas Infection and Alginates, pp. 160-180. Edited by P. Gacesa \& N. J. Russell. London: Chapman \& Hall.

WingENDER, J. \& WINKLER, U. K. (1984). A novel biological function of alginate in Pseudomonas aeruginosa and its mucoid mutants: stimulation of exolipase. FEMS Microbiology Letters 21, 6369.

Yanisch-Perron, C., Vieira, J. \& Messing, J. (1985). Improved M13 phage cloning vectors and host strains: nucleotide sequences of the M13mp18 and pUC19 vectors. Gene 33, 103-119. 